\title{
Changes of Liver Fat Contents in Rats Fed the Low Energy Diet during Pregnancy
}

\author{
Mamoru Saitoh and Seiya TAKahashi \\ Department of Nutrition, National Institute of Animal Industry, Aobacho, Chiba-shi 280
}

(Received February 21, 1974)

\begin{abstract}
The changes of fat content in the liver of dam during pregnancy in the rats fed the low or high energy diet and the cause of the fat accumulation in the liver were mainly investigated. The results obtained are summarized as follows. In the high energy group (digestible energy: $4.8 \mathrm{kcal} / \mathrm{g}$ ), the liver fat content markedly decreased with the progress of pregnancy. On the contrary, the fat content in the low energy group markedly increased with the progress of pregnancy, that is, liver fat content on day 19 of pregnancy was about 1.6 times greater than that on day 7 of pregnancy. The fat accumulation in the liver in the low energy group was significantly alleviated by the addition of linoleic acid and/or choline chloride. As it is commonly known that choline is biosynthesized, it was concluded that the fat accumulation in the liver in the low energy group was mainly due to the insufficiency of essential fatty acids in the low energy diet. The fetal fat content was significantly increased by the addition of linoleic acid and/or choline chloride. The embryonic survival rate was not affected by the addition of linoleic acid. The addition of choline chloride, however, significantly increased the embryonic wastage rate. About $50 \%$ of the total embryonic wastage occurred during the middle stage of pregnancy.
\end{abstract}

In our previous paper ${ }^{\prime \prime}$, it was found that the embryonic wastage in the pregnant rats fed the low energy diet (digestible energy: $2.3 \mathrm{kcal} / \mathrm{g}$ ) was markedly lower than that in the high energy group (digestible energy: $4.8 \mathrm{kcal} / \mathrm{g}$ ). The livers on day 19 of pregnancy in the rats fed the low energy diet were abnormally whity and the fatty droplet was observed on the surface of the liver at autopsy. It was assumed that this phenomenon might be due to the accumulation of fat in the liver. Therefore, the changes of fat content in the liver of the dam during pregnancy and the cause of the fat accumulation in the liver were mainly investigated in this paper.

\section{Materials and Methods}

\section{Experiment 1}

Experimental diets: The compositions of experimental diets used in this experiment are shown in detail in our previous paper'). Digestible energy (DE) contents of the low and high enegy diets were 2.3 and $4.8 \mathrm{kcal} / \mathrm{g}$, respectively. The diets differed mainly in $\mathrm{DE}$ content. Adequate amounts of vitamins and minerals for good growth and reproduction were contained in both diets. The energy levels corresponded to about $60 \%$ and $120 \%$, respectively, of the requirement estimated by the National Research Council (NRC) ${ }^{2)}$ for the pregnant rat. The linoleic acid content (calculated value) in the low energy diet was $0.03 \%$, 


\section{Liver Fat Contents during Pregnancy in Rats}

and this level corresponded to only about $14 \%$ of the requirement for the pregnant rat estimated by the $\mathrm{NRC}^{\text {a) }}$.

Animals, mating method and feeding levels: Virgin female rats of the Wistar Strain, 10 to 11 weeks old and weighing 200 to $240 \mathrm{~g}$, were mated, two females with one male during a single estrous cycle. The experimental diet was given from the day when sperms were found in the vaginal smear (day 0 of pregnancy). The rats were kept in individual cages after mating. Animals were killed on days 7, 14 and 19 of pregnancy by decapitation and the liver was removed. The daily feeding levels in both dietary groups were 16,18 and $20 \mathrm{~g}$ from days 0 to 6 of pregnancy, days 7 to 13 and days 14 to 19 , respectively". As the rats which did not completely consume the diet fed were observed only in the high energy group, they ( 6 rats out of a total 56, 10.7\%) were discarded from this experiment. Only the rats which completely consumed the diet fed were used. Drinking water was always available. The temperature of the room was maintained at about $23^{\circ} \mathrm{C}$.

Fat analysis: The liver was dried at $105^{\circ} \mathrm{C}$ for 6 to 8 hours and the dry matter weight was weighed. Fat was determined by subjecting the dried ground liver to continuous ethyl ether extraction for 16 hours on the Soxleht apparatus and by weighing the ether-soluble material $^{8)}$. The liver fat in the non-pregnant rats (average body weight $200 \mathrm{~g}$ ) was also analyzed 7, 14 and 19 days after the initiation of feeding of the low energy diet. The feeding levels in this group were similar to those of pregnant rats. The fat contents in these samples were represented on the dry weight basis.

The data were treated statistically according to the method outlined by Snedecor ${ }^{4}$.

Experiment 2

As described in Experiment 1, the linoleic acid content in the low energy diet used in this experiment corresponded to only about $14 \%$ of the allowance for the pregnant rat recommended by the $\mathrm{NRC}^{2}$.

On the other hand, it is commonly known that choline alleviates the fat accumulation in the liver. Therefore, the effects of linoleic acid and/or choline chloride on the fat accumulation in the liver found on day 19 of pregnancy in the rats fed the low energy diet were investigated in Experiment 2. The additional level of linoleic acid to the low energy diet was $0.1 \%$ and that of choline chloride was $0.1 \%$ or $0.5 \%$. These diets were given from day 0 of pregnancy. These rats were killed on day 19 of pregnancy. Then the liver, fetuses and placentae were removed. The fat in these samples was analyzed by the same method used in Experiment 1. The feeding levels during different stages of pregnancy were similar to those of Experiment 1. The samples of fetuses and placentae in the low energy group were obtained from the rats used in Experiment 1.

Experiment 3

The uteri and ovaries were also removed from the rats used in Experiment 2 and the number of fetuses and corpora lutea were counted, respectively.

Measurement of the number of corpora lutea: The measurement of the number of corpora lutea was conducted by compressing a fresh whole ovary between two glass slides and making it flat to a certain thickness (about $0.2 \mathrm{~mm}$ ) and observing it with a translucent light ${ }^{5}$. Those in the rats killed on days 14 and 19 of pregnancy were counted under a magnifying glass.

Calculation of the embryonic survival rate: The embryonic survival rate was determined on day 19 of pregnancy. This calculation was based on the assumption that all ova shed were 
fertilized. The survival rate was expressed as the percentage of the number of fetuses to the number of corpora lutea.

\section{Experiment 4}

The embryonic survival rate was the highest in the low energy group and was the lowest in the group supplemented with $0.5 \%$ choline chloride as shown in results of Experiment 3 . In order to elucidate the stage of pregnancy when the highest embryonic wastage occurs, the embryonic wastage rates were determined on days 7,14 and 19 of pregnancy in both groups. The embryonic wastage rates were calculated by subtracting embryonic survival rates from 100. The feeding levels were similar to those of Experiment 1 .

\section{Results}

Liver fat content in the pregnant or non-pregnant rat fed the low or high energy diet: These results are shown in Table 1. In the low energy group, no significant difference was observed in the liver fat content between days 7 and 14 of pregnancy. However, the liver fat content on day 19 of pregnancy was about 1.6 times greater than that on day 7 of pregnancy. On the other hand, the liver fat content in the high energy group markedly decreased with the progress of pregnancy. The liver fat content in the high energy group on day 7 of pregnancy was markedly higher than that of the low energy group, but there was little difference between the two groups on day 14 of pregnancy. Conversely, the content in the low energy group on day 19 of pregnancy was significantly higher than that in the high energy group. In the non-pregnant rats fed the low energy diet, no large variation was observed among the fat contents of the liver in animals killed 7, 14 and 19 days after the initiation of feeding of the diet and also there was no such makedly large fat accumulation in the liver as observed in the pregnant rats fed the low energy diet. Therefore, it is concluded that the markedly large fat accumulation in the liver in the low energy group was a specific phenomenon during the late stage of pregnancy.

Effects of linoleic acid and choline chloride on the liver fat content on day 19 of pregnancy in the rats fed the low energy diet: These results are shown in Table 2. Liver fat content on day 19 of pregnancy was significantly decreased by the addition of linoleic acid and/or choline chloride to the low energy diet. The decrease rate of the liver fat content was the

Table 1. Liver fat content in the pregnant or non-pregnant rat fed the low or high energy diet (Exp. 1)

\begin{tabular}{|c|c|c|c|c|}
\hline \multirow{2}{*}{ Group } & \multirow{2}{*}{$\begin{array}{l}\text { Pregnant or } \\
\text { non-pregnant }\end{array}$} & \multicolumn{3}{|c|}{ Days of pregnancy or days after the initiation of feeding } \\
\hline & & 7 & 14 & 19 \\
\hline \multirow[t]{2}{*}{ Low } & Pregnant & 10. $\frac{3 \pm 1.5 a^{1,2}}{(7)^{3}}$ & $\begin{array}{c}\text { in dry matter }) \\
10.8 \pm 0.9 \mathrm{a}^{1,2} \\
(11)^{3}\end{array}$ & 16. $\int_{(13)^{1}} \cdot a^{1,2}$ \\
\hline & Non-pregnant & $\frac{8.8 \pm 0.6 \mathrm{a}}{(4)}$ & $\frac{9.0 \pm 2.1 \mathrm{~b}}{(4)}$ & $7.8 \pm 1.1 b$ \\
\hline High & Pregnant & $16.0 \pm 2.5 \mathrm{c}$ & $\underset{(5)}{11.2 \pm 2.1} \mathrm{a}, \mathrm{b}$ & 10. $\frac{7 \pm 2.3 \mathrm{c}}{(6)}$ \\
\hline
\end{tabular}

1. Mean \pm S.D.

2. Means within a same column not followed by the same letter ( $a, b$ or $c$ ) are signifcantly different $(\mathrm{P}<0.05)$

3. Figures in parentheses indicate the number of rats used 
Liver Fat Contents during Pregnancy in Rat

Table 2. Effects of linoleic acid and choline chloride on the liver fat content on day 19 of pregnancy in the rats fed the low energy diet (Exp. 2)

\begin{tabular}{lcc}
\hline \multicolumn{1}{c}{ Group $^{1}$} & No. of rats & Liver fat \\
\hline Low & 13 & $(\%$ in dry matter $)$ \\
Low $+0.1 \%$ LA & 9 & $16.5 \pm 1.1 \mathrm{a}, 3$ \\
Low $+0.1 \%$ LA+0.1\% CC & 8 & $12.6 \pm 2.1 \mathrm{~b}$ \\
Low $+0.5 \%$ CC & 6 & $7.0 \pm 3.2 \mathrm{c}$ \\
\hline
\end{tabular}

1. LA: linoleic acid, CC: choline chloride

2. Mean \pm S.D.

3. Means within a same column not followed by the same letter ( $a, b$ or $c$ ) are significantly different $(\mathbf{P}<0.01)$

Table 3. Effects of linoleic acid and choline chloride on fetal and placental weights on day 19 of pregnancy in the rats fed the low energy $\operatorname{diet}$ (Exp. 2)

\begin{tabular}{lccc}
\hline \multicolumn{1}{c}{ Group } & No. of fetuses & Fetus & Placenta \\
\hline or placenta & 162 & $2.21 \pm 0.24 \mathrm{a}^{2,3}$ & $0.34 \pm 0.05 \mathrm{a}^{2,3}$ \\
Low $+0.1 \%$ LA & 101 & $2.05 \pm 0.21 \mathrm{~b}$ & $0.35 \pm 0.06 \mathrm{a}$ \\
Low $+0.1 \%$ LA+0.1\% CC & 96 & $2.05 \pm 0.24 \mathrm{~b}$ & $0.30 \pm 0.07 \mathrm{~b}$ \\
Low $+0.5 \%$ CC & 68 & $2.23 \pm 0.17 \mathrm{a}$ & $0.31 \pm 0.04 \mathrm{~b}$ \\
\hline
\end{tabular}

1. LA: linoleic acid, CC: choline chloride

2. Mean \pm S. D.

3. Means within a same column not followed by the same letter ( $a$ or b) are significantly different $(P<0.001)$

largest in the group maintained by foods supplemented with both linoleic acid and choline chloride.

Effects of linoleic acid and choline chloride on fetal and placental weights on day 19 of pregnancy in the rats fed the low energy diet: These results are shown in Table 3 . The fetal weight was significantly decreased by the addition of linoleic acid and/or choline chloride. However, the addition of choline chloride only did not affect the fetal weight. Therefore, the addition of linoleic acid to the low energy diet decreases the fetal weight. On the other hand, the placental weight was significantly decreased by the addition of linoleic acid and/or choline chloride. However, the addition of linoleic acid only did not affect the placental weight. Accordingly, the addition of choline chloride to the low energy diet decreases the placental weight.

Effects of linoleic acid and choline chloride on the fetal and placental fat contents on day 19 of pregnancy in the rats fed the low energy diet: These results are shown in Table 4. The fetal fat content was significantly increased by the addition of linoleic acid and/or choline chloride. The placental fat content was not increased by the addition of linoleic acid, but was increased by the addition of choline chloride.

Effects of linoleic acid and choline chloride on the embyonic survival rate on day 19 of pregnancy in the rats fed the low energy diet: These results are shown in Table 5 . The 


\section{SaItoH and TaKahashI}

Table 4. Effects of linoleic acid and choline chloride on the fetal and placental fat contents on day 19 of pregnancy in the rats fed the low energy $\operatorname{diet}\left(\right.$ Exp. 2) ${ }^{1}$

\begin{tabular}{lcc}
\hline \multicolumn{1}{c}{ Group $^{2}$} & Fetus & Placenta \\
\hline Low & $4.2 \pm 0.8 \mathrm{a}^{8,4}$ & $(\%$ in dry matter $)$ \\
& $(25)^{6}$ & $7.7 \pm 1.4 \mathrm{a}, \mathrm{c}^{3,4}$ \\
Low $+0.1 \% \mathrm{LA}$ & $5.0 \pm 0.6 \mathrm{~b}$ & $(8)^{\mathrm{s}}$ \\
Low $+0.1 \% \mathrm{LA}+0.1 \% \mathrm{CC}$ & $4.6 \pm 0.5 \mathrm{C}$ & $(9.6 \pm 0.2 \mathrm{a}$ \\
Low $+0.5 \% \mathrm{CC}$ & $5.2 \pm 0.6 \mathrm{~b}$ & $9.3 \pm 0.9 \mathrm{~b}$ \\
& $(18)$ & $(8)$ \\
& $9.2 \pm 1.6 \mathrm{~b}, \mathrm{c}$ \\
\hline
\end{tabular}

1. The analysis of fat for the fetus or placenta was conducted in the lump of 3 to 5 fetuses or all placenta in every dam, respectively

2. LA: linoleic acid, CC: choline chloride

3. Mean \pm S. D.

4. Means within a same column not followed by the same letter ( $a$; $\mathrm{b}$ or $\mathrm{c})$ are significantly different $(\mathrm{P}<0.05)$

5. Figures in parentheses indicate the number of samples

Table 5. Effects of linoleic acid and choline chloride on the embryonic survival rate on day 19 of pregnancy in the rats fed the low energy diet (Exp. 3)

\begin{tabular}{|c|c|c|c|c|}
\hline Group ${ }^{1}$ & No. of rats & $\begin{array}{l}\text { No. of corpora } \\
\text { lutea }\end{array}$ & $\begin{array}{l}\text { No. of } \\
\text { fetuses }\end{array}$ & $\begin{array}{l}\text { Survival } \\
\text { rates }\end{array}$ \\
\hline Low & 13 & $13.6 \pm 1.5 \mathrm{a}, \mathrm{b}^{2,8}$ & 12. $4 \pm 1.3 \mathrm{a}^{2,8}$ & $91.2 \pm 5.2 \%$ \\
\hline Low +0. $1 \%$ LA & 9 & $12.7 \pm 1.0 \mathrm{a}$ & $11.2 \pm 1.6 \mathrm{a}$ & $88.9 \pm 13.6 \mathrm{a}, \mathrm{b}$ \\
\hline Low $+0.1 \% \mathrm{LA}+0.1 \% \mathrm{CC}$ & 8 & $14.5 \pm 2.0 \mathrm{~b}$ & $12.0 \pm 2.6 \mathrm{a}$ & $82.3 \pm 11.5 \mathrm{~b}$ \\
\hline Low $+0.5 \% \mathrm{CC}$ & 6 & $14.3 \pm 2.4 \mathrm{a}, \mathrm{b}$ & $11.3 \pm 1.2 \mathrm{a}$ & $80.6 \pm 12.8 b$ \\
\hline
\end{tabular}

1. LA: linoleic acid, $\mathrm{CC}$ : choline chloride

2. Mean \pm S. D.

3. Means within a same column not followed by the same letter ( $a, b$ or $c$ ) are significantly different $(P<0.05)$

Table 6. Changes of embryonic wastage rates during different periods of pregnancy (Exp. 4)

\begin{tabular}{lccccc}
\hline Group & $\begin{array}{c}\text { No. of } \\
\text { rats }\end{array}$ & $\begin{array}{c}\text { 1st third of } \\
\text { pregnancy } \\
\text { (days 0-7) }\end{array}$ & $\begin{array}{c}\text { 2nd third of } \\
\text { pregnancy } \\
\text { (days 8-14) }\end{array}$ & $\begin{array}{c}\text { Last third of } \\
\text { pregnancy } \\
\text { (days 15-19) }\end{array}$ & Total \\
\hline Low & 6 & $\begin{array}{c}3.1 \\
(32.3)^{2}\end{array}$ & $\begin{array}{c}5.7 \\
(59.4)^{2}\end{array}$ & $\begin{array}{c}2 \\
(8.3)^{2}\end{array}$ & $(100)^{2}$ \\
Low $+0.5 \%$ CC & 6 & 4.9 & 9.2 & 4.4 & 18.5 \\
& $(26.5)$ & $(49.7)$ & $(23.8)$ & $(100)$ \\
\hline
\end{tabular}

1. CC: choline chloride

2. Figures in parentheses indicate the percentage to the total embryonic wastage

embryonic survival rate in the non-supplemented low energy group and in the group supplemented with linoleic acid was about $90 \%$. However, the rate was significantly decreased by 


\section{Liver Fat Contents during Pregnancy in Rat}

the addition of both linoleic acid and choline chloride or the addition of $0.5 \%$ choline chloride only. The results demonstrate that the addition of choline chloride to the low energy diet is harmful for the embryonic survival.

Changes of embryonic wastage rates during different periods of pregnancy: These results are shown in Table 6. The total embryonic wastage rates in the non-supplemented low energy group and in the group supplemented with $0.5 \%$ choline chloride were $9.6 \%$ and $18.5 \%$, respectively. These results were in good agreement with those of Table 5 . Of the total embryonic wastage in the non-supplemented low energy group, the highest embryonic wastage (about $60 \%$ ) occurred during the 2 nd third of pregnancy. During the 1st third of pregnancy the wastage was about $30 \%$. On the other hand, in the group supplemented with $0.5 \%$ choline chloride, about $50 \%$ embryonic wastage occurred during the 2 nd third of pregnancy and during the 1st third and the last third of pregnancy about $25 \%$ of embryos were wasted.

\section{Discussion}

Markedly large fat accumulation in the liver during the late stage of pregnancy was observed in the pregnant rats fed the low energy diet. However, this was significantly alleviated by the addition of linoleic acid and/or choline chloride. It is commonly known that choline is biosynthesized with carbon-chain of serine and methyl radical of methionine. It has been also reported that essential fatty acids contents in the phospholipid fraction decrease and fat accumulates in the liver in the animals fed the essential fatty acids deficient diet $^{6,7}$. Therefore, it is concluded that the main cause of the fat accumulation in the liver found in the low energy group may be the essential fatty acids deficiency. The liver fat content on day 7 was not significantly different from that on day 14 of pregnancy in the low energy group. The content on day 19 of pregnancy in this group increased markedly compared with that of day 7 of pregnancy. These results clearly demonstrate that accumulation of a large amount of the fat in the liver caused by deficiency of the essential fatty acids rapidly occurs after day 15 of pregnancy.

The results of the present experiment indicate that the fetal and placental fat contents were significantly increased by the addition of linoleic acid and/or choline chloride. It has been pointed out as a characteristic point in the fetal fat metabolism that fetuses utilize energy derived from carbohydrates rather than that from fat for the maintenance of energy balance and fat in fetuses is stored to satisfy their requirements after birth, and further this fat accumulation in the fetuses occurs during the late stage of pregnancy ${ }^{83}$. It is an important problem in future whether or not the increase of fatal fat caused by the addition of linoleic acid and/or choline chloride as mentioned above affects the survival rates and growth of young rats after birth. It has been also reported that the transfer of cholesterol, phospholipids and free fatty acids into fetuses was very small and most of the fetal fat seemed to be synthesized by using carbohydrates and the metabolites transferred from the dam ${ }^{8,9)}$. In view of these results, it is assumed that the placental transfer of carbohydrates and the metabolities is increased and fat synthesisin the fetus is accelerated by the addition of linoleic acid and/or choline chloride. To confirm this hypothesis directly, it may be necessary to investigate the quantities of placental transfer of carbohydrates and the metabolities, and further to study the capacity of fat synthesis in either the dam or the fetus in the pregnant rats fed the low energy diet 


\section{SAITOH and TAKAHASHI}

supplemented with linoleic acid and/or choline chloride.

The effects of the essential fatty acids deficiency on the embryonic survival rate were also investigated. No deficiency symptoms of essential fatty acids such as resorptions of the fetuses and stillbirth was observed in the low energy group under this experimental condition. On the other hand, the embryonic wastage rate was significantly increased by the addition of choline chloride to the low energy diet. Further the major part of the embryonic wastage occurred during the 2nd third of pregnancy. But the mechanism about this point remains to be solved.

The authors are greatly indebted to Dr. Kenichi KamвoKa, Head of Nutrition, for supervision, the late Mr. Susumu Fukumrtsu and Dr. Tadashi Sugre for many helpful suggestions and Miss Tani Kishi for her help in language and Mrs. Fusako Usur for care of the animals.

\section{References}

1) Saitor, M., and S. Takahashi, J Nutr 103: 1652-1657. 1973.

2) National Academy of Sciences-National Research Council. Nutrient Requirements of Laboratory Animals. Washington. 25, D. C., 1972.

3) Association of Official Analytical Chemists. Official Methods of Analysis of the Association of Official Analytical Chemists 11th ed. p. 128. Washington. 25, D.C., 1970.

4) Snedecor, G. W., Statistical Methods 5th ed. The Iowa State University Press. Ames, Iowa, 1956.

5) Toyoda, Y., Jap J Anim Reprod 7: 111-115. 1961.

6) Kummerow, F. A., H.P. Pan, and H. Hickman, J Nutr 46: 489-498. 1952.

7) Alfin-Slater, R. B., L. Aftergood, A.F. Wells, and H. J. Deuel, Jr., Arch Biochem Biophys 52: 180-186. 1954.

8) ВавA, K., Seichyo no Seirigaku. Igakushoin. Tokyo. 1966.

9) Koren, Z., and E. Shafrir, Proc Soc Exp Biol Med 116: 411-414. 1964.

\section{弤娠期における低エネルギー飼料給与ラットの肝脂肪について}

$$
\text { 斎藤守・高橋 正也 }
$$

農林省畜産試験場，千葉市 280

\footnotetext{
前回の実験 ${ }^{1}$ において，低エネルギ一飼料(可消化エ ネルギー含量： $2.3 \mathrm{Kcal} / \mathrm{g}$ ) 給与時の好娠 19 日のラッ

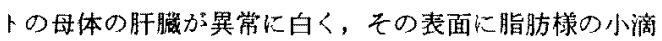
の存在するのが認められた。この現象は，肝臓への脂肪 の暲皘によっているもの上推測されたので，本報では主 として妊娠中の母体の肝茞の脂肪含悬の变化および脂肪 の蓄積の譏作について検討した，その結果，高エネルギ 一区の母体の肝臟の脂肪含量は, 妊娠の准むにつれ著し く減少した。一方，低エネルギー区のそれは妊娠の進行 につれ逆に著しく増加し，娃娠 19 日目では7 日目のそ れの䄪 1.6 倍にも迬した。しかし，この肝腿への脂肪の
}

著しい蓄積は，リノール酸または塩化コリンの添加によ り有意に緩和された。コリンは，生化学的には体内で合 成されることが知られているので，この主因は低エネル ギ一飼料中の必須脂肪酸含量の不足によるものと結諭さ れた，また，胎児の脂肪含量は，リノ一ル酸またはコリ ソの添加により有意に增加した．胚胎の生存率に関して は，リノ一ル酸の添加は，無添加の場合とほほ同じであ った，しかし，塩化コリンを添加した時には，無添加の 場合に比べ有意に低下し，その損耗の約 $50 \%$ までが娃 娠中期に利いて生じていた。 